\title{
Gut microflora of abalone Haliotis discus hannai in culture changes coincident with a change in diet
}

\author{
Reiji TANAKA, Itsuro SUGIMURA, Tomoo SAWABE,* MAmoru YOSHIMIZU AND Yoshio EZURA \\ Laboratory of Microbiology, Graduate School of Fisheries Sciences, Hokkaido University, Hakodate, \\ Hokkaido 041-8611, Japan
}

\begin{abstract}
Development of gut microflora in abalone Haliotis discus hannai cultured at two abalone farms in Japan was similar: (i) gut microflora of juvenile abalones fed on microalgae matched microflora cultured from seawater; and (ii) gut microflora changed coincident with the abalone switching food sources from microalgae to algal pellets. After abalone reached 4 months of age, the gut microflora was replaced by algal polysaccharide-degrading bacteria, which were almost entirely characterized as facultative anaerobes. Dominant species were alginolytic, non-motile fermenters (NMF) and Vibrio spp. The gut microflora seemed to be stable in abalone older than 1 year, with NMF bacteria dominating. Ninety-six percent of the NMF isolates were identified as Vibrio halioticoli by species-specific identification using the colony hybridization method. These results show that abalone $H$. discus hannai has a unique developmental process in which gut microflora shifts to alginate-degrading bacteria, especially $V$. halioticoli.
\end{abstract}

KEY WORDS: abalone, colony hybridization, gut microflora, non-motile fermenter, Vibrio halioticoli.

\section{INTRODUCTION}

Several species of abalone are distributed in coastal areas of Japan. Some are recognized as important marine resources and have a high commercial value in Japan. ${ }^{1}$ In particular, Haliotis discus hannai, which is distributed in coastal areas of northern Japan, ${ }^{2,3}$ is recognized as the most valuable abalone, and aquaculture of this species has been developed in Japan. ${ }^{4}$ Abalone Haliotis spp. are known to feed preferentially on brown algae, and these mollusks are marine herbivores. ${ }^{5}$ Recent studies to improve the growth rate of cultured abalone have focused on developing artificial diets with high feeding efficiencies. Another important point is association between gut microflora and their host, abalone. Controlling gut microbes may be potentially an important factor with high feeding efficiencies.

While many symbiotic relationships of gut organisms have been well studied in ruminant animals and xylophagous insects, ${ }^{6,7}$ the relationships between marine herbivores and their gut microorganisms remain unclear. ${ }^{8}$ Recently, Erasmus et al. ${ }^{9}$

\footnotetext{
*Corresponding author: Tel: 81-138-40-5570.

Fax: 81-138-40-5569. Email: sawabe@fish.hokudai.ac.jp

Received 24 October 2002. Accepted 22 April 2003.
}

attempted to make gnotobiotic Haliotis midae in order to investigate the digestion of algal polysaccharides, and suggested that bacteria resident in the digestive system of $H$. midae assist in the digestion of alginate, laminarin, agarose, carrageenan and cellulose. Similarly, a number of bacteria isolated from the gut of $H$. discuss hannai possess algal polysaccharide-degrading ability. ${ }^{10,11}$ Among them, a unique alginate-degrading bacterium with non-motile and facultative anaerobic characteristics designated as a non-motile fermenter (NMF) was dominant. Subsequently, some of these NMF were identified as Vibrio halioticoli, a new member of the genus Vibrio. ${ }^{12}$ The specificity of the alginate-degrading enzymes in abalone Haliotis spp. is demonstrated by the secretion into the gastrointestinal tract of alginate lyase with substrate specificity for the polymannuronate block, ${ }^{13}$ and the production by $V$. halioticoli of an enzyme with substrate specificity for the polyguluronate block of the alginate molecule. The complete breakdown of alginate is thought to be accomplished by more than one specific enzyme. ${ }^{11}$

Considering the role that gut microorganisms play in digestion, it is important to know when and how gut microflora develop in host animals. Abalones can easily be collected from abalone aquaculture to obtain individuals at various stages of development for investigations of herbivore-gut 
microorganism interactions and/or symbiosis. Here we describe the development of gut microflora in abalone $H$. discus hannai based on the characterization of gut microflora at each growth stage. We focus especially on population changes of alginate-degrading bacteria in the gut of abalone.

\section{MATERIALS AND METHODS}

\section{Abalone samples}

Abalone H.discus hannai were collected at the Kumaishi (Hokkaido) and Ohfunato (Iwate Prefecture) abalone farms from May 1997 to July 1997 (Table 1). Abalone raised in aquaculture for these experiments were switched from microalgae to artificial diets (Nihon Nosan Kogyo, Tokyo, Japan) after 3 months of hatching. The ages of abalone individuals at time of collection are given as time after hatching in days (D) and years (Y). Juveniles fed on microalgae were collected at $80 \mathrm{D}$ and $110 \mathrm{D}$ at Kumaishi (k) and at $120 \mathrm{D}$ at Ohfunato (o). Abalone individuals fed on artificial diets were collected at $1 \mathrm{Y}, 2 \mathrm{Y}$ and $2.5 \mathrm{Y}$ at Kumaishi and at $1 \mathrm{Y}$ at Ohfunato. Additionally, 1Y abalone that was growing larger than the other abalones at Ohfunato was selected (1YLo). Another 1Y abalone group was fed on Laminaria fronds, a type of seaweed (1YSo). The sizes of abalone raised under different culture conditions are shown in Table 1.

\section{Preparation of gut homogenates and enumeration of intestinal bacteria}

The guts of abalone individuals were aseptically excised and a homogenate was prepared as previously described. ${ }^{11}$ The gut of juveniles could not be excised, so the shell was cut away, a homogenate was prepared using the whole body, and bacterial counts were corrected assuming that the gut tissue accounts for $30 \%$ of the whole body on a weightratio basis. The weight ratio $(30 \%)$ was determined by mean value among 50 adult abalones (Tanaka R, unpubl. data, 1997). Supply-seawater and culture-tank seawater were also collected in sterilized bottles and chilled until the use.

Total bacterial counts and viable bacterial counts were determined using 10 -fold serially diluted gut homogenates and seawater samples.

To determine the total bacterial count, $1 \mathrm{~mL}$ of $10 \%$ glutaraldehyde was added to $5 \mathrm{~mL}$ of the $10^{-1}$ and $10^{-2}$ dilutions of gut homogenate or seawater. Then, 4,6-diamino-2-phenilindole (DAPI) was added at a final concentration of $0.5 \mu \mathrm{g} / \mathrm{mL}$ and incubated on ice for $5 \mathrm{~min}$ to stain the bacteria.
Each sample was filtered through a $0.2-\mu \mathrm{m}$ Nuclepore filter (Whatman, Newton, USA) previously stained with Sudan black. Bacterial cells with bluebright fluorescence were counted on an epifluorescent microscope (Axioskop; Carl Zeiss, Göttingen, Germany) equipped with a $75-\mathrm{W}$ mercury light source and no. 1 filter sets. A minimum of 300 DAPI-stained cells from at least 20 microscopic fields were observed for each sample. ${ }^{14}$

Viable bacterial counts were determined according to the method described by Sawabe et al. ${ }^{11}$ Serial 10 -fold dilutions $\left(10^{-1}-10^{-5}\right)$ of gut homogenate and seawater samples $(0.1 \mathrm{~mL})$ were spread on alginate-peptone-yeast extract (APY) agar medium ${ }^{11}$ and incubated at $20^{\circ} \mathrm{C}$ for 7 days. Colonies were counted and expressed as colonyforming units (CFU) per gram of gut (wet weight) for homogenates or as $\mathrm{CFU} / \mathrm{mL}$ for seawater samples.

The most probable number (MPN) of algalpolysaccharides utilizing bacteria was determined in each gut homogenate and seawater sample. Serial 10-fold dilutions of the homogenates and seawater samples were prepared. Then, $0.5 \mathrm{~mL}$ of the dilution was inoculated into $2.5 \mathrm{~mL}$ basal seawater liquid medium ${ }^{15}$ containing algalpolysaccharide for the three-tube method. Alginate, laminarin, mannitol and fucoidan were used for the specific algal polysaccharides, and glucose was used as the control. Cell counts per gram of tissue were computed using the universal equation for MPN. ${ }^{16}$

The gut microflora for each group of abalone were determined. Thirty bacterial colonies were randomly isolated from plates used from the viable counts assay having the appropriate colony counts. All of the bacterial isolates were tentatively characterized using conventional methods. ${ }^{11}$ Alginate-degrading activity was measured by a plate assay previously described by Sawabe et al. ${ }^{11}$

\section{Identification of NMF bacteria using the Vh-probe}

A colony hybridization method using the V.halioticoli genomic probe (Vh-probe) ${ }^{17}$ was applied to 630 abalone bacterial isolates that were previously identified by phenotypic traits. Briefly, each bacterial isolate was grown on ZoBell 2216 ${ }^{11}$ agar for 5 days at $20^{\circ} \mathrm{C}$. Colonies were transferred to a membrane filter (Hybond-N+ Amersham Pharmacia Biotech, Little Chalfont, UK) by overlaying agar plates for $1 \mathrm{~min}$, and the membrane was processed by a denaturation-neutralization step. After fixing bacterial DNA to the membrane by baking, the isolated DNA on the membranes was 


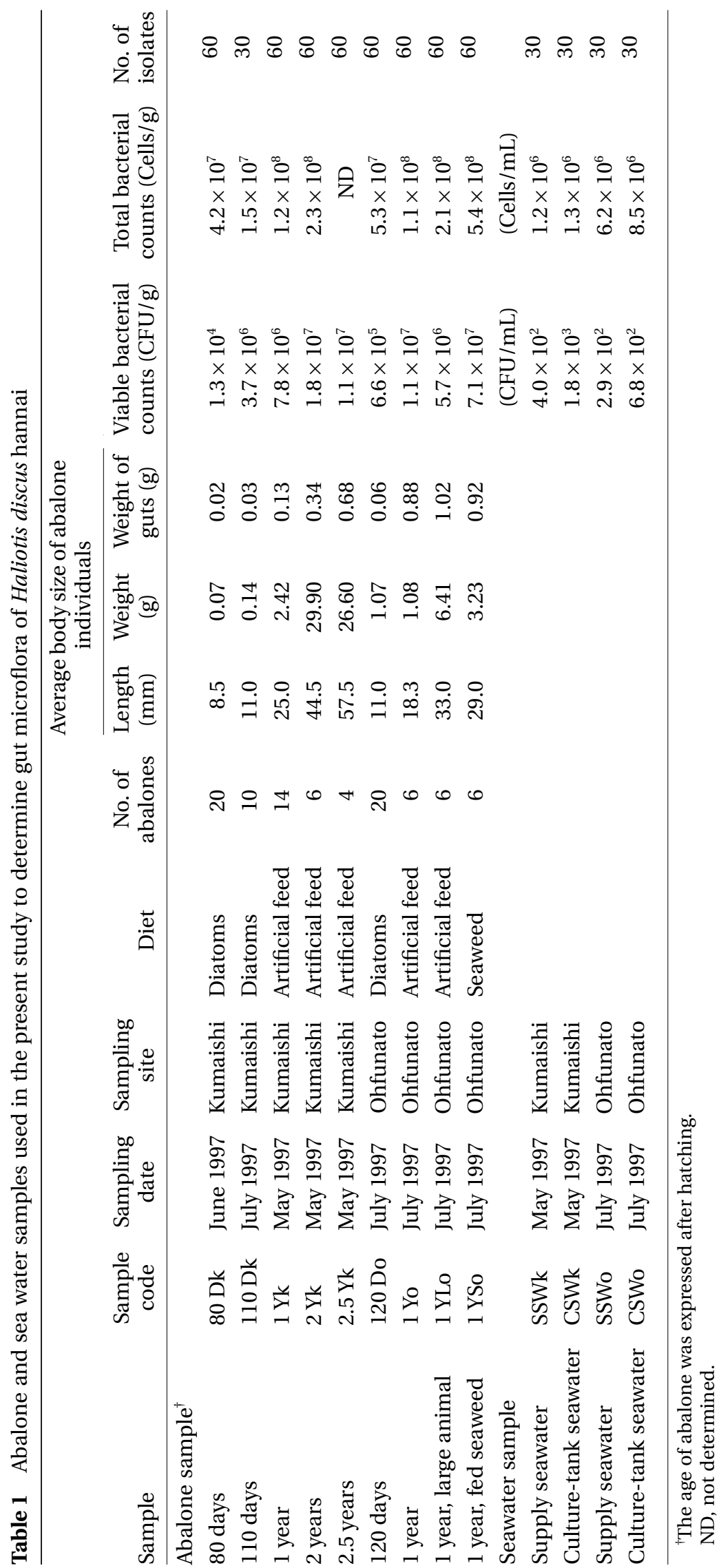


hybridized with alkaline phosphatase-labeled genomic DNA probes of $V$. halioticoli as previously described.$^{17}$ A probe-positive colony was detected by chemical-luminescence using CDP $\operatorname{star}^{\mathrm{TM}}$ detection reagents (Amersham Pharmacia Biotech).

\section{RESULTS}

\section{Bacteria densities}

Bacterial counts of abalone gut homogenates and seawater samples from both Kumaishi and Ohfunato abalone farms are presented in Table 1 . Total bacterial counts of supply-seawater and culturetank seawater at Kumaishi and Ohfunato were all $10^{6}$ cells $/ \mathrm{mL}$ (SSWk, CSWk, SSWo and CSWo) while the viable bacterial counts of supply seawater and culture-tank seawater were $10^{2}-10^{3} \mathrm{CFU} /$ $\mathrm{mL}$ (SSWk, CSWk, SSWo and CSWo). Total and viable bacterial counts increased in abalones fed on artificial diets compared to those fed on microalgae. Total bacterial counts and viable bacterial counts of the gut homogenates of juvenile abalones fed on diatoms were $10^{7}$ cells/g and $10^{4}-$ $10^{6} \mathrm{CFU} / \mathrm{g}$ (80Dk, 110Dk and 120Do), respectively. Counts for 1-year-old abalone fed on artificial diets were slightly increased at $10^{8}$ cells/g ( $1 \mathrm{Yk}$ and 1Yo), and $10^{6}-10^{7} \mathrm{CFU} / \mathrm{g}$ (1Yk and 1Yo), respectively.

\section{Algal polysaccharide-utilizing bacteria}

Results of MPN counts of algal polysaccharide (alginate, laminarin, mannitol, and fucoidan)-utilizing bacteria are shown in Fig. 1. With the exception of fucoidan-utilizing bacteria, the MPN counts were greater in gut samples of 1-2.5-year-old abalones (1Yk, 1Yo, 1YLo, 1YSo, 2Yk and 2.5Yk) compared to juvenile abalones (80Dk, 110Dk and 120Do) at both farms. MPN counts of alginate-, laminarinand mannitol-utilizing bacteria were at similar levels to those for basal seawater media supplemented with glucose as a carbon source. MPN counts of algal polysaccharide-utilizing bacteria were $10-100$ cells $/ \mathrm{mL}$ in culture-tank seawater samples at both farms (Fig. 1).

\section{Characterization of the bacterial isolates}

Dominance of alginate-degrading bacteria depended on the age of the abalone (Fig. 2). Juvenile abalones fed on diatoms had a very low percentage of alginolytic bacteria $(10-25 \%, 80 \mathrm{Dk}, 110 \mathrm{Dk}$ and (a)
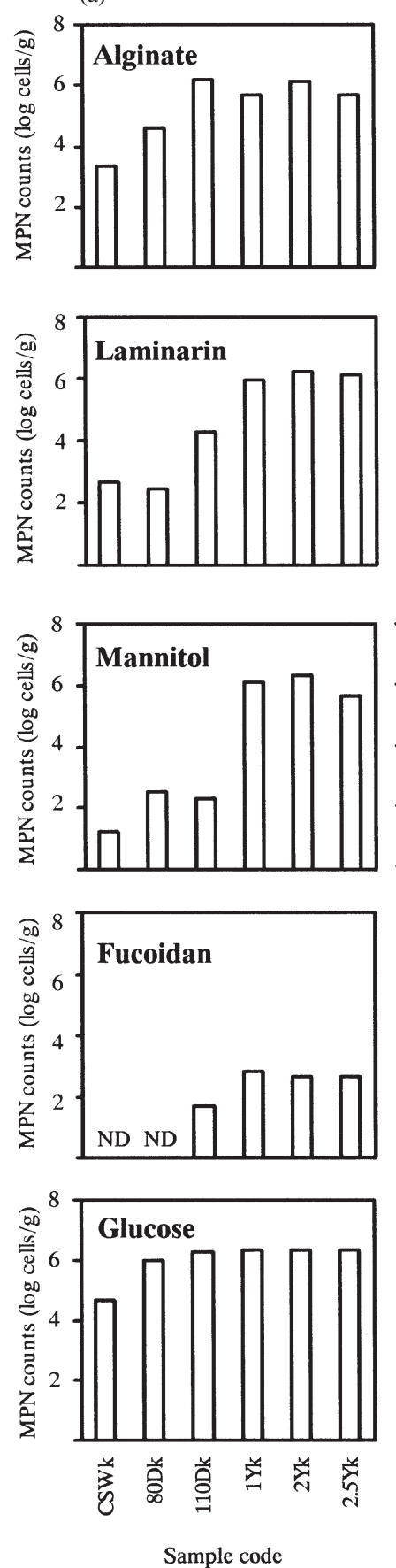

(b)
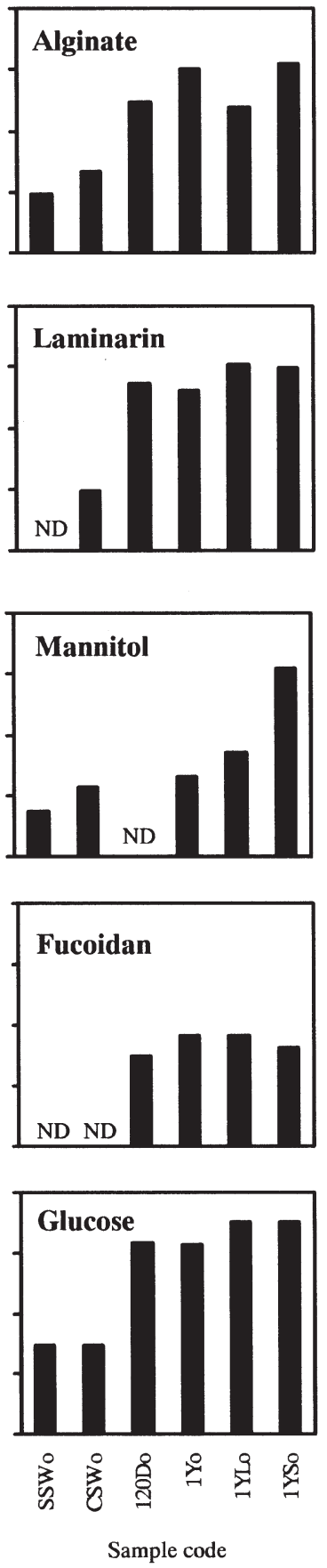

Fig. 1 Most probable number (MPN) counts of algal polysaccharides-utilizing bacteria in the gut of abalone Haliotis discus hannai. Four kinds of polysaccharides (alginate, laminarin, mannitol and fucoidan) were used in the present study. Glucose was used as control of MPN counts. Abalone samples were collected at (a) Kumaishi and (b) Ohfunato stations.

120Do). However, alginate-degrading bacteria accounted for more than $58 \%$ of bacteria isolated from 1 to 2.5 -year-old abalones (1Yk, $2 \mathrm{Yk}, 2.5 \mathrm{Yk}$, 1Yo, 1YLo, and 1YSo). 
(a)

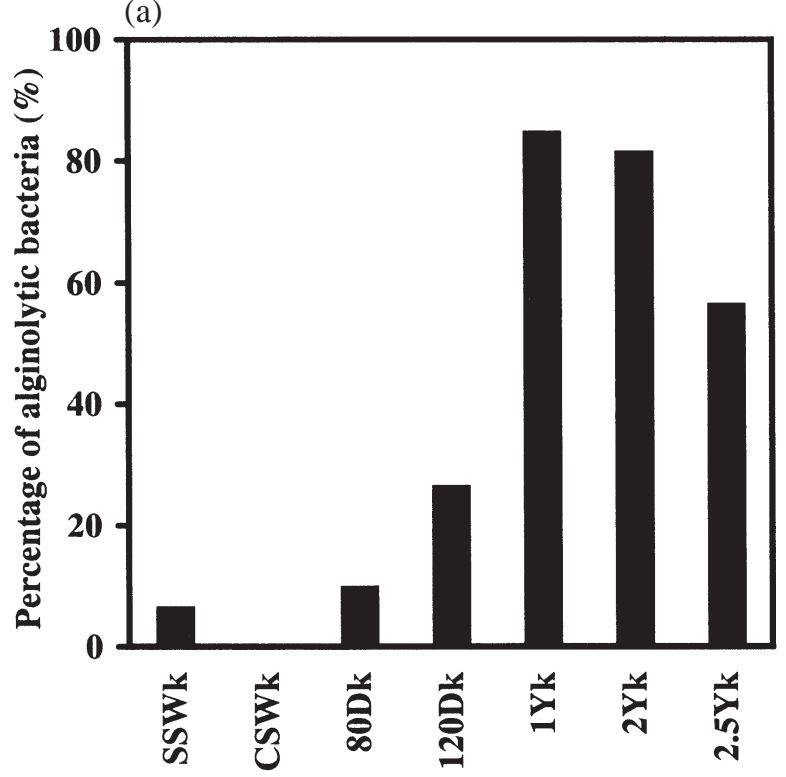

Sample code

(b)

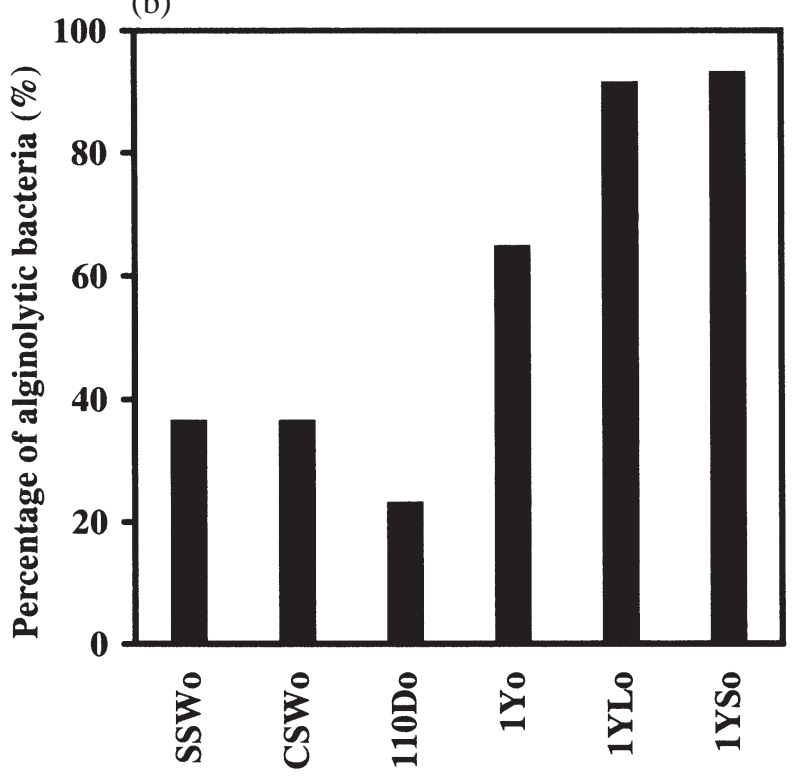

Sample code

Fig. 2 Percentage of alginate-degrading bacteria in the gut of abalone Haliotis discus hannai. Abalone samples were collected at (a) Kumaishi and (b) Ohfunato stations.

Gut microflora and seawater samples from both Kumaishi and Ohfunato were represented by five genera (Fig. 3): NMF, ${ }^{11}$ Vibrio, Pseudomonas, Alteromonas and Cytophaga. Supply seawater (SSWk) and culture-tank seawater (CSWk) consisted mainly of aerobic bacteria (Pseudomonas and Alteromonas). Juvenile abalone (80Dk) fed on dia- (a)

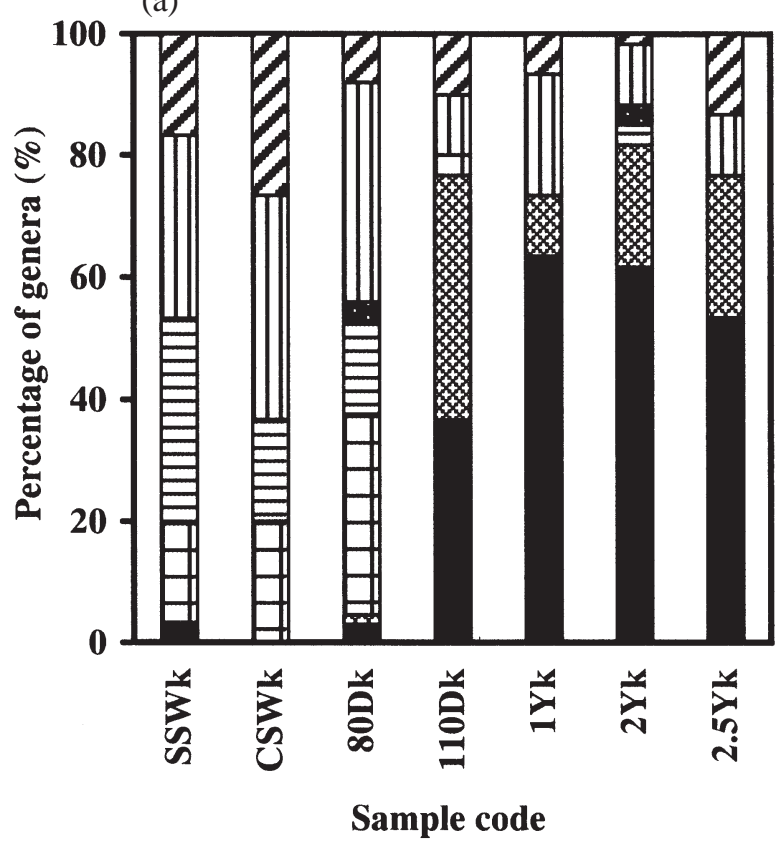

(b)

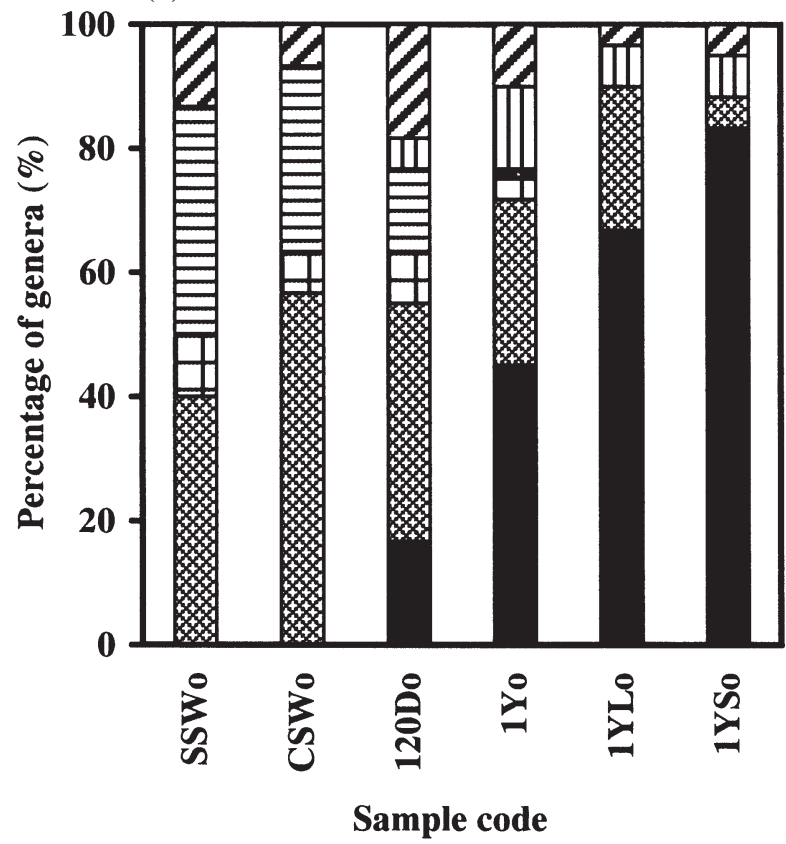

Fig. 3 Bacterial flora of the gut of abalone Haliotis discus hannai and that of seawater samples collected at (a)

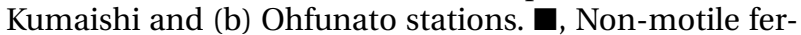
menters (NMF); Vibrio; $\square$, Pseudomonas; E, Alteromonas; $\mathbb{Z}$, Cytophaga; 四, other genera; $\mathbf{D}$, unidentified.

toms had almost the same microflora as supply seawater. Gut microflora composition changed slightly between the 4-month-old stage and the 1year-old stage when abalone individuals were fed on artificial diets containing seaweed powder. In 1- 
year-old abalone (1Yk), a total of $75 \%$ of the bacterial isolates were identified as facultative anaerobes: $64 \%$ were identified as $\mathrm{NMF}^{11}$ and $10 \%$ were identified as Vibrio. In 2-year-old abalone (2Yk), $85 \%$ of the bacterial isolates were identified as facultative anaerobes: $62 \%$ were identified as NMF, and $20 \%$ were identified as Vibrio. Gut microflora composition of 2.5-year-old abalone was almost the same as that of 1-year-old and 2-year-old abalone. In samples collected at Ohfunato, $40 \%$ of the microflora of supply seawater (SSWo) and that of the culture-tank seawater sample (CSWo) were Vibrio. NMF accounted for $16 \%$ of the microflora of juveniles (120Do), but were dominant (more than $40 \%$ ) in 1-year-old abalone (1Yo, 1YLo, 1YSo). The greatest dominance of NMF was observed in 1-year-old abalone fed on Laminaria frond (1YSo).

\section{Identification of NMF bacteria using the Vh-probe}

Of the 247 NMF isolates identified by phenotypic characterization, 238 bacterial isolates were confirmed as $V$. halioticoli by the colony hybridization with the Vh-probe (Table 2). No false positives were detected in the 413 bacterial isolates identified as non-NMF by phenotypic methods.

\section{DISCUSSION}

The development of gut microflora in the abalone $H$. discus hannai was investigated over developmental stages coincident with changing diets from two abalone farms, Kumaishi and Ohfunato. Haliotis discus hannai is known as a cold-water adapted species of $\mathrm{H}$. discus, ${ }^{2}$ with a distribution in the north part of Japan extending as far south as Iwate prefecture, the southern boundary of successful aquaculture of this species. Aquaculture conditions were similar at Kumaishi and Ohfunato, with exceptions in seawater temperature and origin of supply seawater. Fertilization and hatching of $H$. discus hannai took place in March and April; during the 4-day swimming larvae period, juvenile abalones were cultured on a feeding panel seeded with microalgae. Artificial diets were begun around or after 3 months of age, and abalone were released to coastal areas or transferred to mariculture stations.

MPN counts of alginate-, laminarin- and mannitol-utilizing bacteria were comparable between seawater samples and gut homogenates of juvenile abalones fed on diatoms. MPN counts of algal-polysaccharide-utilizing microorganisms changed slightly from approximately the 4 monthold stage when abalones started feeding on artificial diets (Fig. 1). Alginate-utilizing bacteria also increased during the shift from diatoms to artificial diets. Finally, alginate-, laminarin- and mannitolutilizing bacteria were also abundant in 1-2-yearold abalones. Rather low percentages of alginatedegrading bacteria were observed in juvenile abalones (Fig. 2). The gut microflora of juvenile abalones fed on diatoms was almost identical with the supply seawater. Alginate-degrading bacteria increased around 4 months and were highest in abalones cultured for 1-2 years. These results indicate that the gut microflora of abalone forms at the period when artificial diets are fed, and comprised algal polysaccharide-degrading or -utilizing bacteria. In salmonid fish, it has been reported that

Table 2 Identification of Vibrio halioticoli using colony hybridization among 630 isolates from the gut of abalone and seawater samples

\begin{tabular}{|c|c|c|c|c|c|c|c|c|c|c|c|c|c|c|}
\hline \multirow[b]{3}{*}{ Sample } & \multirow{2}{*}{\multicolumn{2}{|c|}{ NMF }} & \multirow{2}{*}{\multicolumn{2}{|c|}{ Vibrio }} & \multicolumn{8}{|c|}{ No. strains } & & \\
\hline & & & & & \multicolumn{2}{|c|}{$\begin{array}{l}\text { Pseudo- } \\
\text { monas }\end{array}$} & \multicolumn{2}{|c|}{ Alteromonas } & \multicolumn{2}{|c|}{ Cytophaga } & \multicolumn{2}{|c|}{ Other genera } & \multicolumn{2}{|c|}{ Unidentified } \\
\hline & PC & $\mathrm{CH}$ & PC & $\mathrm{CH}$ & PC & $\mathrm{CH}$ & PC & $\mathrm{CH}$ & PC & $\mathrm{CH}$ & PC & $\mathrm{CH}$ & PC & $\mathrm{CH}$ \\
\hline SSWk & 1 & 1 & 0 & 0 & 6 & 0 & 9 & 0 & 0 & 0 & 3 & 0 & 11 & 0 \\
\hline CSWk & 0 & 0 & 0 & 0 & 6 & 0 & 5 & 0 & 0 & 0 & 16 & 0 & 3 & 0 \\
\hline 80Dk & 1 & 1 & 1 & 0 & 20 & 0 & 9 & 0 & 1 & 0 & 22 & 0 & 6 & 0 \\
\hline $110 \mathrm{Dk}$ & 11 & 10 & 12 & 0 & 1 & 0 & 0 & 0 & 0 & 0 & 3 & 0 & 3 & 0 \\
\hline $1 \mathrm{Yk}$ & 38 & 36 & 6 & 0 & 0 & 0 & 0 & 0 & 2 & 0 & 12 & 0 & 2 & 0 \\
\hline $2 \mathrm{Yk}$ & 37 & 35 & 12 & 0 & 0 & 0 & 2 & 0 & 2 & 0 & 6 & 0 & 1 & 0 \\
\hline $2.5 \mathrm{Yk}$ & 32 & 32 & 14 & 0 & 0 & 0 & 0 & 0 & 0 & 0 & 6 & 0 & 8 & 0 \\
\hline SSWo & 0 & 0 & 12 & 0 & 2 & 0 & 11 & 0 & 0 & 0 & 4 & 0 & 1 & 0 \\
\hline CSWo & 0 & 0 & 16 & 0 & 2 & 0 & 9 & 0 & 0 & 0 & 0 & 0 & 3 & 0 \\
\hline 120Do & 10 & 9 & 23 & 0 & 5 & 0 & 8 & 0 & 0 & 0 & 3 & 0 & 11 & 0 \\
\hline 1Yo & 27 & 27 & 16 & 0 & 2 & 0 & 0 & 0 & 1 & 0 & 8 & 0 & 6 & 0 \\
\hline 1YLo & 40 & 38 & 14 & 0 & 0 & 0 & 0 & 0 & 0 & 0 & 4 & 0 & 2 & 0 \\
\hline 1YSo & 50 & 49 & 3 & 0 & 0 & 0 & 0 & 0 & 0 & 0 & 4 & 0 & 3 & 0 \\
\hline Total & 247 & 238 & 129 & 0 & 44 & 0 & 53 & 0 & 6 & 0 & 91 & 0 & 60 & 0 \\
\hline
\end{tabular}

$\mathrm{CH}$, Vh-probe positive strain among colony hybridization; NMF, non-motile fermenters; PC, phenotypic characterization. 
intestinal microflora are formed only when the intestine and the intestinal tissues begin to work properly. ${ }^{18}$ The gut microflora of abalone begins to change coincident with a change in food type. More research into the development of gut and gut tissues of the abalone is needed.

More than $60 \%$ of alginate-degrading bacteria isolated from abalone individuals were identified as NMF. Most NMF were identified as Vibrio halioticoli, which is a new member of the genus Vibrio ${ }^{12}$ by the colony hybridization method. Furthermore, we have developed another method for identifying $V$.halioticoli using a fingerprinting technique based on 16S rDNA polymerase chain reaction/restriction fragment length polymorphism from NMF isolates. ${ }^{19}$ We applied this method to 17 randomly selected bacterial isolates out of the 247 NMF isolates, and confirmed the identity as V. halioticoli (Tanaka R, unpubl. data, 2000).

Recently, V. halioticoli strains have been identified in the gut of three other species of Haliotidae abalones ( $H$. discus discus, $H$. divorsicolor divorsicolor and $H$. divorsicolor aquatilis ${ }^{20}$ and from seawater around abalone farms in Japan. ${ }^{21}$ Wide distribution of $V$.halioticoli, and abundance of $V$. halioticoli in the gut microflora of three other Haliotidae abalones suggest a strong association between this bacterium and the host abalone, and may confirm the important role of algal polysaccharide catabolism in symbiotic or commensal associations.

The present study revealed that abalone $H$. discus hannai has a unique process of developing gut microflora. Interestingly, there are some differences between total cell counts and viable counts of gut homogenates as large as one order of magnitude per gram of tissue (Table 1). Identification of the uncultured bacteria (obligate anaerobes, oligotrophs, archaebacteria and other groups) is needed to completely describe the microbes and host-microbe interactions of the abalone. In future experiments, we will attempt to make a clone library to survey the microbial diversity of gut contents. A $16 \mathrm{~S}$ rDNA gene library obtained from gut of abalone and in situ whole-cell hybridization $^{22}$ should allow identification of the majority of gut microflora of abalone. Artificially replacing the gut microflora of abalones using antibiotics will allow us to obtain further information about the gut microbial community of marine invertebrates.

\section{ACKNOWLEDGMENTS}

We thank Mr T Kodama at the Kumaishi abalone farming station, Dr T Shibui and Mr S Komatsu at the Ohfunato abalone farming station, and $\mathrm{Mr} \mathrm{T}$ Noro at Iwate Fisheries Technology Center for providing abalone samples. This work was partly supported by a Grant-in-Aid for Scientific Research (No. 09460081) from the Ministry of Education, Science and Culture of Japan and by a Research Fellowship of the Japan Society for the Promotion of Science for Young Scientists.

\section{REFERENCES}

1. Oakes FR, Ponte RD. The abalone market: Opportunities for cultured abalone. Aquaculture 1996; 140: 187-197.

2. Ino T. Biological studies on the propagation of abalone (genus Haliotis). Bull. Tokai Reg. Fish Res. Lab. 1952; 5: 1102.

3. Naganuma T, Hisadome K, Shiraishi K, Kojima H. Molecular distinction of two resemblant abalones, Haliotis discus discus and Haliotis discus hannai by $18 \mathrm{~S}$ rDNA sequences. J. Mar. Biotechnol. 1998; 6: 59-61.

4. Yamakawa H. Abalone culture. In: Kafuku T, Ikenoue H (eds). Modern Methods of Aquaculture in Japan. Kodansha, Tokyo. 1983; 172-182.

5. Uki N, Sugiura M, Watanabe T. Dietary value of seaweeds occurring on the pacific coast of Tohoku for growth of the abalone Haliotis discus hannai. Nippon Suisan Gakkaishi 1986; 52: 257-266.

6. Breznak JA. Intestinal microbiota of termites and other xylophagous insects. Ann. Rev. Microbiol. 1982; 36: 323-343.

7. Ohkuma M, Kudo T. Phylogenetic diversity of the intestinal bacterial community in the termite Reticulitermes speratus. Appl. Environ. Microbiol. 1996; 62: 461-468.

8. Harris JM. The presence, nature, and role of gut microflora in aquatic invertebrates: a synthesis. Microb. Ecol. 1993; 25: 195-231.

9. Erasmus JH, Cook PA, Coyne VE. The role of bacteria in the digestion of seaweed by the abalone Haliotis midae. Aquaculture 1997; 155: 377-386.

10. Ohnishi T, Suzuki M, Kikuchi R. The distribution of polysaccharide hydrolase activity in gastropods and bivalves. Nippon Suisan Gakkaishi 1985; 51: 301-308.

11. Sawabe T, Oda Y, Shiomi Y, Ezura Y. Alginate Degradation by bacteria isolated from the gut of sea urchins and abalones. Microb. Ecol. 1995; 30: 193-202.

12. Sawabe T, Sugimura I, Ohtsuka M, Nakano K, Tajima K, Ezura Y, Christen R. Vibrio halioticoli sp. nov., a non-motile alginolytic marine bacterium isolated from the gut of the abalone Haliotis discus hannai. Int. J. Syst. Bacteriol. 1998; 48: $573-580$.

13. Nakada HI, Sweeny PC. Alginolytic acid degradation by eliminases from abalone hepatopancreas. J. Biol. Chem. 1967; 242: 845-851.

14. Kepner JR, Pratt JR. Use of fluorochromes for direct enumeration of total bacteria in environmental samples: past and present. Microbial. Rev. 1994; 58: 603-615.

15. Baumann P. Alteromonas. In: Krieg NR, Holt JG (eds). Bergey's Manual of Systematic Bacteriology, Vol 1. Williams \& Wilkins, Baltimore. 1984; 314-352.

16. Taylor J. The estimation of numbers of bacteria by tenfold dilution series. J. Appl. Bacteriol. 1962; 25: 54-61. 
17. Tanaka R, Ootsubo M, Sawabe T, Tajima K, Vandenberghe J, Ezura Y. Identification of Vibrio halioticoli by colony hybridization with non-radioisotope labeled genomic DNA probe. Fish. Sci. 2002; 68: 227-229.

18. Yoshimizu M, Kimura T, Sakai M. Microflora of the embryo and the fry of salmonids. Nippon Suisan Gakkaishi 1980; 46 : 967-975.

19. Tanaka R, Sawabe T, Tajima K, Vandenberghe J, Ezura Y. Identification of Vibrio halioticoli using 16S rDNA PCR/ RFLP (restriction fragments length polymorphism) analysis. Fish. Sci. 2001; 67: 185-187.

20. Sawabe T, Thompson FL, Heyrman J, Cnockaert M, Hayashi K, Tanaka R, Yoshimizu M, Hoste B, Swings J, Ezura
Y. Fluorescent amplified fragment length polymorphism (FAFLP) and repetitive extragenic palindrome (rep)-PCR fingerprinting reveal host-specific genetic diversity of Vibrio halioticoli-like strains isolated from the gut of Japanese abalone. Appl. Environ. Microbiol. 2002; 68: 41404144 .

21. Tanaka R, Sawabe T, Yoshimizu M, Ezura Y. Distribution of Vibrio halioticoli around an abalone farming center in Japan. Microb. Environ. 2002; 17: 6-9.

22. Amann RI, Ludwig W, Schleifer KH. Phylogenetic identification and in situ detection of individual microbial cells without cultivation. Microbiol. Rev. 1995; 59: 143169 . 